\title{
A Rare Case of Metformin Intoxication with Mortal Course
}

\section{Mortal Seyreden Nadir Bir Metformin Intoksikasyonu Olgusu}

\author{
Merve OSOYDAN SATICI $\odot$, Abdullah ALGIN $\odot$, Gokhan AKSEL $\odot$, Serkan Emre EROGLU $\odot$
}

Ethics Committee Approval: Not Applicable.

Conflict of Interest: The authors declare that they have no conflict of interest. Funding: None.

Informed Consent: Informed consent was taken.
Cite as: Osoydan Satici M, Algin A, Aksel G, Eroglu SE. A rare case of metformin intoxication with mortal course. Medeniyet Med J. 2020;35:175-8.

\begin{abstract}
Metformin-associated lactic acidosis is a rare side effect in metformin poisoning. There is conflicting data about mortality rates changing from 3\% to $83 \%$. We aimed to discuss a case that developed lactic acidosis and acute renal failure progressing to mortality due to metformin intoxication. A 33 year-old female patient was admitted to the emergency department, with nausea and vomiting after taking 30 tablets of $1000 \mathrm{mg}$ metformin. In the 2nd hour of follow-up, patient was observed to develop lactic acidosis which did not recover despite the infusion replacement treatments and hemodialysis. Following the development of respiratory failure, under mechanical ventilation, the patient developed cardiac arrest at the 48th hour of her admission. In metformin intoxications, it should be remembered that acidosis deepens very quickly and can progress with mortality despite optimal supportive therapy. More specific recommendations and further studies are required for the management and treatment of acute metforminassociated lactic acidosis.
\end{abstract}

Keywords: Metformin, lactic acidosis, intoxication, acute kidney injury

öz

Metformin ile ilişkili laktik asidoz, metformin zehirlenmesinde nadir görülen bir yan etkidir. Mortalite oranı hakkında \%3'ten \%83'e değişen çelişkili veriler mevcuttur. Bu çalışmada metformin zehirlenmesine bağlı laktik asidoz ve akut böbrek yetmezliği gelişen ve mortalite ile sonuçlanan bir olguyu tartışmayı amaçladık. 33 yaşında kadın hasta, 30 adet $1000 \mathrm{mg}$ metformin tablet içtikten sonra acil servise bulantı ve kusma ile başvurdu. Takibinin 2. saatinde laktik asidoz gelişstiği gözlendi, infüzyon replasman tedavilerine ve hemodiyalize rağmen metabolik asidozun derinleştiği görüldü. Solunum yetmezliği gelişen ve mekanik ventilasyon desteği verilen hastada, başvurusunun 48. saatinde kardiyak arrest gelişti. Metformin zehirlenmesine bağlı gelişen asidozun çok hızlı derinleştiği ve optimal destekleyici tedaviye rağmen mortaliteye ilerleyebileceği unutulmamalıdır. Akut metformin ilişkili laktik asidozun yönetimi ve tedavisinde daha spesifik önerilere ve daha ileri çalışmalara ihtiyaç vardır.

Anahtar kelimeler: Metformin, laktik asidoz, zehirlenme, akut böbrek hasarı
Received: 9 May 2020

Accepted: 25 May 2020

Online First: 30 June 2020

Corresponding Author: M. Osoydan Satici

ORCID: 0000-0002-3169-0724 Umraniye Training and Research Hospital, Department of Emergency Medicine, Istanbul, Turkey

merveosoydan@gmail.com

A. Algin
ORCID: 0000-0002-9016-9701
G. Aksel
ORCID: 0000-0002-5580-3201
S. Emre Eroglu
ORCID: 0000-0002-3183-3713
Umraniye Training and
Research Hospital, Department of
Emergency Medicine,
Istanbul, Turkey




\section{INTRODUCTION}

Metformin is a reliable oral antidiabetic agent belonging to the biguanide group, which is the primary option, especially for non-insulin dependent diabetes mellitus (DM) ${ }^{(1)}$. Lactic acidosis is the most serious side effect of metformin use and it is the most important reason of the mortality in patients who has metformin intoxication but there are conflicting data regarding incidence of mortality. According to the data of the US poison center, 9 of 300 cases of intentional metformin overdose were mortal (3\%) ${ }^{(2)}$. However, in one review, 5 cases of 6 deliberate metformin overdoses were mortal $(83 \%)^{(3)}$.

The key management of metformin toxicity is based on ventilation and circulation support. Supportive therapy and resuscitation are essential and there is no specific antidote. Gastrointestinal decontamination should be considered in early admissions. It is important to prevent hypothermia and maintain body temperature. Bicarbonate therapy should be considered in patients with optimal ventilation and $\mathrm{pH}$ level below 7.0. Since sodium bicarbonate infusions alone cannot adequately correct acid-base metabolism, hemodialysis is recommended for metformin clearance and the treatment of acidosis ${ }^{(4)}$. Performing hemodialysis in the early period is the cornerstone of treatment to prevent mortality.

In our case report, we aimed to discuss a rare case with lactic acidosis and acute renal failure with progressing mortality despite performing early hemodialysis.

\section{CASE}

A 33-year-old female patient with known Type 2 DM, receiving metformin therapy only, admitted to the emergency department with nausea and vomiting that started 2 hours after committing suicide by taking 30 tablets of metformin $1000 \mathrm{mg}$ $(0.4 \mathrm{gr} / \mathrm{kg}$ total$)$. Her general condition was good, vital parameters were as follows: blood pressure: 120/70 $\mathrm{mmHg}$, heart rate: 90 per minute, respiration rate: 22 per minute. $\mathrm{spO}_{2}: \% 97$ and no pathological finding was found in the physical examination of the patient. Electrocardiography showed 1:1 atrioventricular nodal conduction sinus rhythm with normal QRS and QTc distances.

After the gastric lavage and activated coal (1 g/ $\mathrm{kg}$ ) therapy, hydration and symptomatic treatment were started.

No abnormality was observed in the patient's first hemogram, liver and kidney function tests and no electrolyte imbalance was detected. Her blood gas analysis in admission was as follows: $\mathrm{pH}: 7.37$, $\mathrm{pCO}_{2}: 78.1 \mathrm{mmHg}, \mathrm{HCO}_{3}: 19.6 \mathrm{mmol} / \mathrm{L}$, lactate: $4.7 \mathrm{mmol} / \mathrm{L}$ and glucose: $186 \mathrm{mg} / \mathrm{dl}$.

In the $2^{\text {th }}$ hour of her follow-up, the patient's general condition worsened and confusion developed and her vital signs were: blood pressure: 100/67 $\mathrm{mmHg}$, pulse: 100 beats/min, $\mathrm{spO}_{2}: 99 \%$. In the control physical examination, widespread tenderness was observed in the abdomen, and no defenses and rebounds were detected. Creatinine in control laboratory parameters was seen to increase as $2.2 \mathrm{mg} / \mathrm{dl}$. Control arterial blood gas parameters were as follows: $\mathrm{pH}: 7.27, \mathrm{pCO}_{2}: 25.5$ $\mathrm{mmHg}, \mathrm{pO}_{2}: 75 \mathrm{mmHg}$, lactate: $9 \mathrm{mmol} / \mathrm{L}, \mathrm{hCO}_{3}$ : $10.6 \mathrm{mmol} / \mathrm{L}$, anion gap: 23.4, glucose: $80 \mathrm{mg} /$ dL. The patient was observed to develop lactic acidosis with high anion gap due to metformin. Early hemodialysis was thought to be needed and the patient was followed up closely. Subsequent arterial blood gas parameters were as follows: $\mathrm{pH}: 6.89, \mathrm{pCO}_{2}: 19.5 \mathrm{mmHg}, \mathrm{pO}_{2}: 75 \mathrm{mmHg}$, lactate: $18 \mathrm{mmol} / \mathrm{L}, \mathrm{hCO}_{3}: 5.6 \mathrm{mmol} / \mathrm{L}$, anion gap: 33.4, glucose: $52 \mathrm{mg} / \mathrm{dL}$. Treatment of hypoglycemia was started by applying intravenous 20\% Dextrose 125 cc. After intravenous 100 mEq (1.5 $\mathrm{mEq} / \mathrm{kg}$ ) sodium bicarbonate $\left(\mathrm{NaHCO}_{3}\right)$ bolus was administered, $100 \mathrm{mEq} \mathrm{NaHCO}_{3}$ infusion was started. The patient, who had urinary output of 4 $\mathrm{cc} / \mathrm{kg} /$ hour, was taken to hemodialysis early, as 
metabolic acidosis did not improve in serial blood gas follow-ups (Figure 1) despite the infusion replacement treatments. It was observed that lactic acidosis continued to deepen in the patient who was transferred to the intensive care unit after 2 hours of hemodialysis and continuous veno-venous hemodiafiltration (CVVHF) was applied due to ongoing resistant metabolic acidosis.

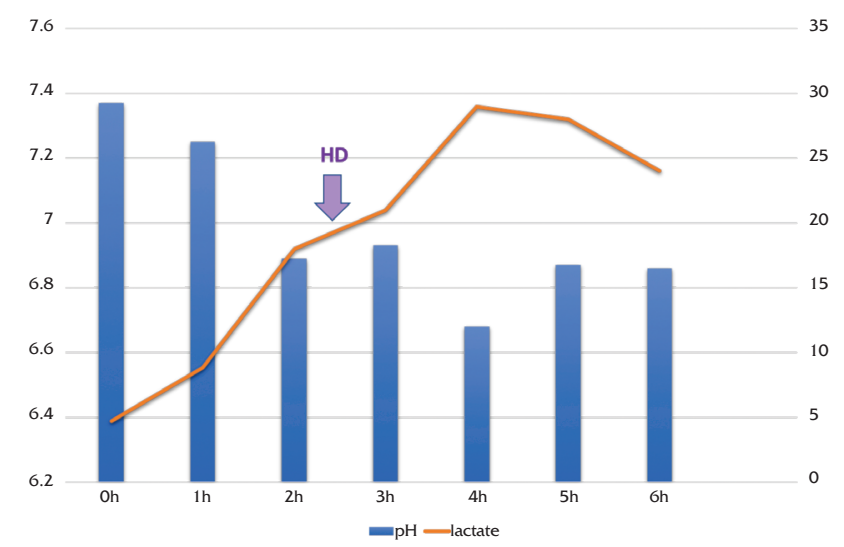

Figure 1. pH and lactate values in arterial blood gas analysis obtained in 1 hour intervals.

Abbreviations: $p H$ : potential of hydrogen HD: hemodialysis application

Patient who developed respiratory failure in the intensive care unit and invasive mechanical ventilation treatment was initiated, cardiac arrest developed at the $48^{\text {th }}$ hour of her admission. After 45 minutes of cardiopulmonary resuscitation, patient was accepted as exitus.

\section{DISCUSSION}

In our case who is a young adult patient, metformin intoxication led to acute renal failure and end up with mortality despite performing early hemodialysis.

Metformin intoxication should be suspected in a diabetic patient with high anion gap metabolic acidosis. Anamnesis and clinical findings are sufficient for diagnosis and measuring metformin level is not necessary in most cases as in our case ${ }^{(3,5)}$. Although the minimum dose of metformin causing toxicity is uncertain; it has been reported that possible lethal dose concentration $>50 \mathrm{mg} / \mathrm{L}^{(3)}$. In the literature, a case has been reported in which serious side effects, especially Type B lactic acidosis, may develop after 5 gr overdose ${ }^{(6)}$.

Various data are available in the literature regarding the factors predicting mortality in metformin intoxication. In a case series in which 42 patients with metformin poisoning included and mortality was seen as $48 \%$, it was stated that the strongest predictor of mortality was liver dysfunction, especially increased prothrombin time ${ }^{(7)}$. A systematic review of studies reporting acute metformin overdosing revealed that low serum $\mathrm{pH}$ and high serum lactate concentrations are associated with increased mortality ${ }^{(3)}$. In our case, although liver dysfunction was not observed, mortality occured with increased lactate level and decreased $\mathrm{pH}$ level in follow-up.

Lalau et al. ${ }^{(8)}$ stated a case series that 13 cases of metformin intoxication were examined, a patient with highest lactate level as $4.2 \mathrm{mmol} / \mathrm{L}$ was treated with gastric lavage only and did not need alkalization or hemodialysis. In a case reported by Lacher et al. (9), a patient with lactate level up to $20.6 \mathrm{mmol} / \mathrm{L}$ and creatinine. up to $2.4 \mathrm{mg} / \mathrm{dL}$, was successfully treated with intravenous sodium bicarbonate replacement and hemodialysis. Although sodium bicarbonate replacement is widely used, its place in treatment is controversial.

In a literature review, it has been reported that it is vital and the most common toxicological indication for extracorporeal treatments (ECTR) in metformin poisoning ${ }^{(10)}$. It has been reported that mortality rate decreases with early hemodialysis or CVVHF treatment in metformin intoxication cases resulting from suicide ${ }^{(11)}$. However in another study a case treated with a short-term hemodialysis session, a rebound increase in lactate production has been reported ${ }^{(12)}$. In our case, the highest lactate level was measured as $28 \mathrm{mmol} / \mathrm{L}$; and despite sodium bicarbonate therapy, early hemodialysis and CVVHF, mortality has developed. 


\section{CONCLUSION}

It should be remembered that acidosis deepens very quickly and can progress with mortality despite optimal supportive therapy. So, more specific recommendations and further studies are required for the management and treatment of acute metformin associated lactic acidosis.

\section{REFERENCES}

1. Stumvoll M, Nurjhan N, Perriello G, Dailey G, Gerich JE. Metabolic effects of metformin in noninsulin dependent diabetes mellitus. N Engl J Med. 1995;333:550-4. [CrossRef]

2. Bronstein AC, Spyker DA, Cantilena LR Jr, Green J, Rumack BH, Heard SE. 2006 Annual report of the American Association of Poison Control Centers National Poison Data System (NPDS). Clin Toxicol (Phila). 2007;45:815917. [CrossRef]

3. Dell'Aglio DM, Perino LJ, Kazzi Z, Abramson J, Schwartz $\mathrm{MD}$, Morgan BW. Acute metformin overdose: examining serum $\mathrm{pH}$, lactate level, and metformin concentrations in survivors versus nonsurvivors: a systematic review of the literature. Ann Emerg Med. 2009;54:818-23. [CrossRef]
4. Yang PW, Lin KH, Lo SH, Wang LM, Lin HD. Successful treatment of severe lactic acidosis caused by a suicide attempt with a metformin overdose. Kaohsiung J Med Sci. 2009;25:93-7. [CrossRef]

5. Lalau JD, Race JM. Lactic acidosis in metformin therapy: searching for a link with metformin in reports of 'metformin-associated lactic acidosis'. Diabetes Obes Metab. 2001;3:195-201. [CrossRef]

6. Forrester $M B$. Adult metformin ingestions reported to Texas poison control centers, 2000-2006. Hum Exp Toxicol. 2008;27:575-83. [CrossRef]

7. Seidowsky A, Nseir S, Houdret N, Fourrier F. Metforminassociated lactic acidosis: a prognostic and therapeutic study. Crit Care Med. 2009;37:2191-6. [CrossRef]

8. Lalau JD, Mourlhon C, Bergeret A, Lacroix C. Consequences of metformin intoxication. Diabetes Care. 1998;21:2036-7. [CrossRef]

9. Lacher $M$, Hermanns-Clausen $M$, Haeffner $K$, Brandis $M$, Pohl M. Severe metformin intoxication with lactic acidosis in an adolescent. Eur J Pediatr. 2005;164:362-5. [CrossRef]

10. Mardini J, Lavergne V, Roberts D, Ghannoum M. Case reports of extracorporeal treatments in poisoning: Historical trends. Semin Dial. 2014;27:402-6. [CrossRef]

11. Barrueto F, Meggs WJ, Barchman MJ. Clearance of metformin by hemofiltration in overdose. J Toxicol Clin Toxicol. 2002;40:177-80. [CrossRef]

12. Kruse JA. Metformin-associated lactic acidosis. J Emerg Med. 2001;20:267-72. [CrossRef] 